\title{
Childhood Esophageal Carcinoma
}

National Cancer Institute

\section{Source}

National Cancer Institute. Childhood Esophageal Carcinoma. NCI Thesaurus. Code C118812.

A rare carcinoma of the esophagus that occurs during childhood. 